\title{
Analisis Risiko Teknologi Informasi Menggunakan ISO 31000 (Learning Management System SMPN 6 Salatiga)
}

\author{
Pandhu Kanantyo ${ }^{1}$, Frederik Samuel Papilaya ${ }^{2}$ \\ ${ }^{1,2}$ Sistem Informasi, Fakultas Teknologi Informasi, Universitas Kristen Satya Wacana \\ ${ }^{3}$ Jl. Blotongan, Sidorejo, Kota Salatiga, Jawa Tengah \\ e-mail:kanantyop@gmail.com ${ }^{1}$, samuel.papilaya @gmail.com²
}

\begin{abstract}
Abstrak
SMP Negeri 6 Salatiga merupakan salah satu sekolah yang berada di Kota Salaatiga yang saat ini sudah menggunakan e-learning sejak tahun 2017 untuk membantu dalam kegiatan belajar mengajar di sekolahan. Aplikasi Moodle, merupakan e-learning yang digunakan oleh SMP Negeri 6 Salatiga. Aplikasi ini memiliki fungsi untuk memperbaharui, menyimpan, mendistribusikan serta membagi materi belajar mengajar untuk para guru dan murid. Namun aplikasi Moodle ini sering mengalami berbagai masalah seperti server yang sering down, web service mati secara tiba-tiba, koneksi jaringan sering terputus. Masalah - masalah seperti ini dapat mengganggu kegiatan belajar siswa, maka dari itu penelitian ini membahas tentang manajemen risiko menggunakan framework ISO 31000, untuk mengetahui segala bentuk risiko terhadap aplikasi Moodle, sehingga risiko dapat di minimalisir, serta dapat diatasi oleh pihak sekolah. Hasil akhir dari penelitian ini berupa rekomendasi untuk mengatasi serta meminimalisir risiko yang ada.
\end{abstract}

Kata kunci-analisis risiko, manajemen risiko, ISO 31000

\begin{abstract}
SMP Negeri 6 Salatiga is one of the schools in the City of Salaatiga which has been using e-learning since 2017 to assist in teaching and learning activities in school. The Moodle application is an e-learning application used by SMP Negeri 6 Salatiga. This application has a function to update, store, distribute and share teaching and learning materials for teachers and students. However, this Moodle application often experiences various problems such as servers that are often down, web services suddenly shut down, and network connections are often lost. Problems like this can interfere with student learning activities, therefore this study discusses risk management using the ISO 31000 framework, to find out all forms of risk to the Moodle application, so that risks can be minimized, and can be overcome by the school. The final result of this research is in the form of recommendations to overcome and minimize the existing risks.
\end{abstract}

Keywords — ISO 31000, risk analysis, risk management 9

\section{PENDAHULUAN}

$\mathrm{S}$ MPN 6 Salatiga adalah salah satu sekolah unggulan yang berada di wilayah bagian selatan kota Salatiga. Untuk mendukung proses pembelajaran, SMPN 6 Salatiga saat ini juga menggunakan e-learning yang sudah digunakan sejak tahun 2017. Media yang digunkan merupakan aplikasi Moodle yang sudah disesuikan dengan kebutuhan. Terlebih lagi dimasa pandemi seperti ini sekolah dituntut untuk melakukan pembelajaran secara daring atau online atau pembelajaran jarak jauh (PJJ). 
Seiring dengan perkembangan jaman, penggunaan TIK khususnya internet untuk pendidikan di Indonesia terus berkembang. Pengembangan pendidikan menuju e-learning merupakan suatu keharusan agar standar mutu pendidikan dapat ditingkatkan, karena e-learning merupakan penggunaan teknologi internet dalam penyampaian pembelajaran dalam jangkauan luas yang berlandaskan tiga kriteria yaitu: (1) e-learning merupakan jaringan dengan kemampuan untuk memperbaharui, menyimpan, mendistribusi dan membagi materi ajar atau informasi, (2) pengiriman sampai ke pengguna terakhir melalui komputer dengan menggunakan teknologi internet yang standar, (3) memfokuskan pada pandangan yang paling luas tentang pembelajaran di balik paradigma pembelajaran tradisional, dengan demikian urgensi teknologi informasi dapat dioptimalkan untuk pendidikan. [1].

Pembelajaran e-Learning merupakan prinsip pembelajaran langsung dimana dalam penerapannya e-learning mengedepankan pembelajaran mandiri yaitu pembelajaran jarak jauh berbasis web yang bisa diakses melalui jaringan internet. Oleh karena itu, diperlukan suatu aplikasi untuk mendukung pembelajaran e-learning. Aplikasi yang digunakan adalah Moodle berbasis LMS (Learning Management System). LMS merupakan sebuah sistem yang didesain untuk menampilkan, melacak, melaporkan, dan mengatur konten pembelajaran, kemajuan siswa, dan interaksi siswa.[2].

Dalam pelaksanaannya tentu terdapat berbagai tantangan dan risiko yang dapat mengancam proses pembelajaran jarak jauh. Oleh karena itu peneliti ingin berusaha untuk menganalisis risiko apasaja yang mungkin bisa mengancam media pembelajaran online atau daring yang dapat menghambat atau bahkan menghalangi proses pembelajaran jarak jauh (PJJ) menggunakan framework ISO 31000[3].

Berdasarkan penelitian sebelumnya yang dilakukan oleh Driantami, Suprapto dan Perdanakusuma pada tahun 2018 mengenai manajemen risiko menggunakan ISO 31000:2009 dengan framework NIST 800-30 dengan studi kasus: Sistem Penjualan PT Matahaari Departement Store Cabang Malang Town Aquare. Dari penelitian yang dilakukan terdapat tiga point penting yang dapat diambil antara lain: (1) Untuk manajemen risiko menggunakan framework ISO 31000 membutuhkan framework yang lebih teknis seperti NIST 800-30. (2) Dengan menggunakan ISO 31000 terlihat nilai risiko dengan tiga tingkatan yaitu rendah, sedang, dan tinggi. (3) Rekomendasi pengendalian yang tepat seperti risk reduction untuk risiko human error (kesalahan dalam mengoperasikan sistem), risk avoidance untuk risiko pencurian password otorisasi, serta risk reduction untuk risiko koneksi yang tidak stabil.[4]

Lalu juga penelitian yang dilakukan oleh Rilyani, Firdaus dan Jatmiko pada tahun 2015 melakukan analisis risiko teknologi informasi menggunakan ISO 31000 dengan studi kasus: IGgracial Telkom University. Setelah melakukan serangkaian proses manajemen risiko, maka didapatkan hasil tingkatan risiko pada sistem i-Gracias. Risiko yang berada pada level tinggi adalah risiko yang memiliki nilai kemungkinan dan nilai dampak yang tinggi. Pada sistem iGracias, risiko yang memiliki nilai risiko paling tinggi adalah Database Server Down. Dampak yang ditimbulkan apabila risiko tersebut terjadi adalah seluruh layanan i-Gracias tidak dapat berjalan sehingga perlu dilakukan penanganan secara cepat terhadap risiko tersebut.[5] 


\section{METODE PENELITIAN}

\subsection{Kajian Pustaka}

\subsubsection{ISO 31000}

ISO 31000 adalah suatu standar implementasi manajemen risiko yang diterbitkan oleh International Organization for Standardization pada tanggal 13 November 2009. Standar ini ditujukan untuk dapat diterapkan dan disesuaikan untuk semua jenis organisasi dengan memberikan struktur dan pedoman yang berlaku generik terhadap semua operasi yang terkait dengan manajemen risiko. Menurut ISO 31000, manajemen risiko suatu organisasi harus mengikuti 11 prinsip dasar agar dapat dilaksanakan secara efektif. Berikut penjabaran prinsipprinsip tersebut. Yaitu : Manajemen risiko menciptakan nilai tambah, Manajemen risiko adalah bagian integral proses dalam organisasi, Manajemen risiko adalah bagian dari pengambilan keputusan, Manajemen risiko secara eksplisit menangani ketidakpastian Manajemen risiko bersifat sistematis, terstruktur, dan tepat waktu, Manajemen risiko berdasarkan informasi terbaik yang tersedia, Manajemen risiko dibuat sesuai kebutuhan, Manajemen risiko memperhitungkan faktor manusia dan budaya, Manajemen risiko bersifat transparan dan inklusif, Manajemen risiko bersifat dinamis, iteratif, dan responsif terhadap perubahan, Manajemen risiko memfasilitasi perbaikan dan pengembangan berkelanjutan organisasi.[6]2.1.2 Perencanaan Strategis Sistem Informasi.

\subsubsection{Manajemen Risiko}

Manajemen risiko adalah suatu proses mengidentifikasi, mengukur risiko, serta membentuk strategi untuk mengelolanya melalui sumber daya yang tersedia. Manejemen risiko bertujuan untuk mengelola risiko sehingga dapat memperoleh hasil yang optimal[7]. Agar dapat berjalan dengan baik, manajemen risiko diletakkan dalam suatu kerangka manajemen risiko. erangka kerja ini akan menjadi dasar dan penataan yang encakup seluruh kegiatan manajemen risiko di segala tingkatan organisasi, selain itu juga akan membantu organisasi mengelola risiko secara efektif melalui penerapan proses manajemen risiko. Kerangka kerja ini tidak dimaksudkan sebagai sebuah sistem manajemen, tetapi lebih ditujukan untuk membantu organisasi mengintegrasikan manajemen risiko ke dalam keseluruhan sistem manajemen organisasi. Oleh karena itu, organisasi harus mengadopsi komponen-komponen dari kerja ini ke dalam kebutuhan khas organisasi[8].

\subsection{Tahap Penelitian.}

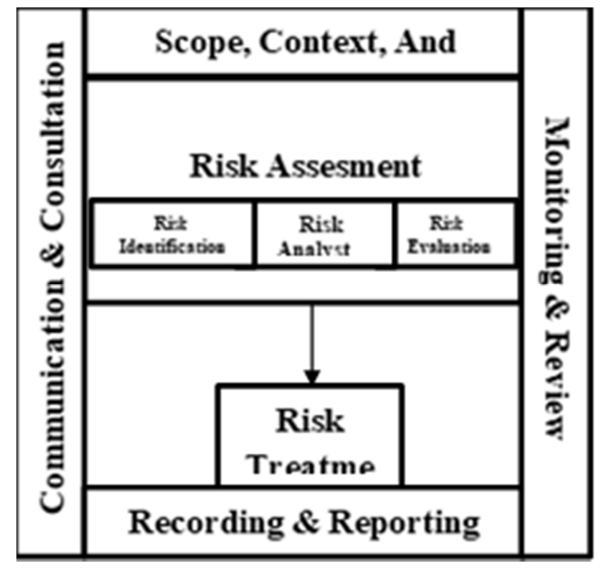

Gambar 1. Tahap Penelitian

Kanantyo, et., al [Analisis Risiko Teknologi Informasi Menggunakan ISO 31000 (Learning Management System SMPN 6 Salatiga)] 
Metode penelitian yang digunakan peneliti menggunakan metode penelitian kualitatif. Penelitian kualitatif merupakan penelitian yang digunakan untuk menyelidiki, menemukan, menggambarkan, dan menjelaskan kualitas atau keistimewaan dari pengaruh social yang tidak dapat dijelaskan, diukur atau digambarkan melalui pendekatan kuantitatif pada suatu studi kasus yang alamiah dan dengan memanfaatkan berbagai metode alamiah[9].

Salah satu metode yang digynakan dalam penelitian ini adalah Case Study Research, yaitu fokus dalam metode ini hanya pada satu objek studi kasus. Penerapan metode case study research ini, bertujuan agar peneliti dapat berfokus pada objek penelitian yang lebih mendalam dengan begitu peneliti dapat mengumpulkan data yang diperlukan agar lebih terpusat[10].

Pada pengelolaan manajemen risiko di SMPN 6 Salatiga ini, peneliti menggunakan framework ISO 31000. Dimana ISO 31000 berfokus pada manajemen risiko. Dalam perkembanganya, ISO 31000 juga secara resmi diakui sebagai standar manajemen risiko di hingga 40 negara dunia. Dalam penelitian ini metode yang digunakan peneliti dilakukan dengan berbagai tahap. Tahapan ini selaras dengan framework ISO 31000, dimana dengan melakukan riset, dalam mencari segala macam data dan informasi yang valid serta digunakan untuk penelitian pada e-learning di SMPN 6 Salatiga dengan menggunakan pendekatan dari pihak peneliti kepada pihak internal dalam penelitian ini dengan cara wawancara untuk menggali data primer yang bersumber dari narasumber atau orang yang berkaitan langsung dengan e-learning SMPN 6 Salatiga.

Dalam pengambilan data untuk penelitian ini yaitu dengan melakukan wawancara terhadap narasumber yaitu bagian TI dari SMPN 6 Salatiga.

Dengan begitu, peneliti dapat menentukan penilaian risiko atau Risk Assesment. Penilaian risiko ini merupakan sebuah metode yang banyak digunakan dalam perusahaan maupun organisasi untuk menentukan risiko. Dalam melakukan sebuah risk assesment terdapat beberapa tahap.

1. Identifikasi Risiko (Risk Identification)

2. Identifikasi risiko adalah melakukan suatu identifikasi atas segala kemungkinankemungkinan risiko dengan cara mengumpulkan data dan informasi yang valid.

3. Analisis Risiko (Risk Analyst)

4. Dilakukan untuk mengetahui berbagai level risiko yang sudah ditemukan, yang mengancam bagi perkembangan e-learning di SMPN 6 Salatiga

5. Evaluasi Risiko (Risk Evaluation)

6. Evaluasi risiko adalah sebuah proses untuk membandingkan tingkat level risiko sesuai dengan kriteria risiko yang sudah ditetapkan. Level risiko ini diurutkan dari yang terendah sampai level risiko yang tertinggi.

Selanjutnya masuk dalam tahap Perlakuan Risiko (Risk Treatment) dalam tahap ini dilakukan penanggulangan risiko yaitu dengan pemilihan satu atau lebih cara yang dilakukan untuk menanggulangi risiko yang sudah ditemukan serta mengimplementasikan penerapan penanganan risiko tersebut. Setelah diimplementasikan, penanganan risiko dapat dinilai efektifitasnya apakah tingkat risiko tersebut dapat diteloransi atau tidak, jika penanganan risiko tidak dapat ditoleransi maka akan menghasilkan penanganan risiko yang baru[5].

\section{HASIL DAN PEMBAHASAN}

\subsection{Penilaian Risiko}

Pada tahap penilaian risiko terdiri dari 3 tahapan, yaitu tahap identifikasi risiko, tahap analisis risiko, dan tahap evaluasi risiko.

Kanantyo, et., al [Analisis Risiko Teknologi Informasi Menggunakan ISO 31000 (Learning Management System SMPN 6 Salatiga)] 
a. Identifikasi Risiko

Setelah melakukan identifikasi aset pada aplikasi Moodle, langkah berikutnya perlu dilakukan identifikasi kemungkinan risiko, dengan mengelompokkan berdasarkan faktor-faktor yang kerap muncul seperti pada faktor alam atau lingkungan, faktor SDM, serta faktor sistem dan infrastruktur. Seperti yang terlihat pada tabel identifikasi kemungkinan risiko di tabel 1.

Tabel 1. Identifikasi Kemungkinan Risiko

\begin{tabular}{|c|c|c|}
\hline Faktor & Id & Kemungkinan Risiko \\
\hline \multirow{5}{*}{ Alam atau Lingkungan } & R01 & Banjir \\
\hline & R02 & Gempa Bumi \\
\hline & R03 & Petir \\
\hline & R04 & Kebakaran \\
\hline & R05 & Listrik Padam \\
\hline \multirow{5}{*}{ Manusia } & R06 & Human Error \\
\hline & R07 & $\begin{array}{l}\text { Data dan Informasi diakses oleh pihak yang tidak } \\
\text { berwenang }\end{array}$ \\
\hline & R08 & Penyalahgunaan hak akses \\
\hline & R09 & Vandalisme \\
\hline & $\mathrm{R} 10$ & Cybercrime \\
\hline \multirow{16}{*}{$\begin{array}{l}\text { Sistem dan } \\
\text { Insfrastruktur }\end{array}$} & R11 & Server down \\
\hline & $\mathrm{R} 12$ & Backup Failure \\
\hline & $\mathrm{R} 13$ & Overhead \\
\hline & R14 & Data corrupt \\
\hline & $\mathrm{R} 15$ & Overcapacity \\
\hline & R16 & Overload \\
\hline & $\mathrm{R} 17$ & Web service mati secara tiba-tiba \\
\hline & R18 & Koneksi jaringan terputus \\
\hline & R19 & Koneksi jaringan tidak stabil \\
\hline & R20 & Sistem Crash \\
\hline & $\mathrm{R} 21$ & Gagal update \\
\hline & R22 & Memori penuh \\
\hline & $\mathrm{R} 23$ & Kegagalan software \\
\hline & R24 & Kegagalan hardware \\
\hline & $\mathrm{R} 25$ & Serangan virus \\
\hline & R26 & Proses maintenance tidak terjadwal \\
\hline
\end{tabular}

b. Identifikasi Dampak Risiko

Setelah dilakukan tahap identifikasi risiko, beberapa kemungkinan risiko ditemukan dari beberapa faktor seperti faktor alam, lingkungan, serta sistem dan infrastruktur yang dapat berpotensi kinerja dari aplikasi Moodle, maka pada langkah berikutnya dapat dilihat detail dari identifikasi dampak risiko pada Tabel 2. 
Tabel 2 Identifikasi Dampak Risiko

\begin{tabular}{|c|c|c|}
\hline Id & $\begin{array}{l}\text { Kemungkinan } \\
\text { Risiko }\end{array}$ & Dampak \\
\hline R01 & Banjir & $\begin{array}{l}\text { Terjadi kerusakan infrastruktur dan menghambat aktivitas } \\
\text { bisnis Perusahaan. }\end{array}$ \\
\hline R02 & Gempa Bumi & $\begin{array}{l}\text { Terjadi kerusakan insfrastruktur dan proses bisnis Perusahaan } \\
\text { terhenti }\end{array}$ \\
\hline R03 & Petir & $\begin{array}{l}\text { Mengalami kerusakan infrastrutur pada perusahaan dan } \\
\text { mengalami kerugian secara finansial. }\end{array}$ \\
\hline R04 & Kebakaran & $\begin{array}{l}\text { Terjadi kerusakan infrastruktur perusahaan, proses bisnis } \\
\text { terhenti, instansi mengalami kerugian secara finansial. }\end{array}$ \\
\hline R05 & Listrik Padam & Seluruh akifitas pada perusahaan terhenti \\
\hline R06 & Human Error & $\begin{array}{l}\text { Proses layanan pada pengoroman data tidak berjalan secara } \\
\text { optimal }\end{array}$ \\
\hline R07 & $\begin{array}{l}\text { Data dan } \\
\text { Informasi } \\
\text { diakses oleh } \\
\text { pihak yang } \\
\text { tidak } \\
\text { berwenang }\end{array}$ & $\begin{array}{l}\text { Mengakibatkan kebocoran informasi data an memungkinkan } \\
\text { manipulasi data }\end{array}$ \\
\hline R08 & $\begin{array}{l}\text { Penyalahgunaan } \\
\text { hak akses }\end{array}$ & $\begin{array}{l}\text { Mengakibatkan kebocoran informasi data an memungkinkan } \\
\text { manipulasi data }\end{array}$ \\
\hline R09 & Vandalisme & $\begin{array}{l}\text { Dapat mengakibatkan kerusakan pada hardware maupun } \\
\text { perangkat lainya }\end{array}$ \\
\hline R10 & Cybercrime & Adanya manipulasi data serta pencurian data \\
\hline R11 & Server down & Kegagalan dalam melakukan akses ke server \\
\hline R12 & Backup Failure & Meningkatkan risiko kehilangan data \\
\hline $\mathrm{R} 13$ & Overhead & $\begin{array}{l}\text { Kinerja hardware kurang maksimal, karena rusaknya hardware } \\
\text { yang harus menanggung suhu panas yang terus menerus }\end{array}$ \\
\hline R14 & Data corrupt & Dapat mengalami kehilangan daata \\
\hline $\mathrm{R} 15$ & Overcapacity & $\begin{array}{l}\text { Kapasitas memori penuh sehingga database tidak dapat } \\
\text { menampung data berlebih }\end{array}$ \\
\hline R16 & Overload & $\begin{array}{l}\text { Kehilangan data dan proses loading terhambat karena log } \\
\text { database, log temp dan log temp database terisi penuh }\end{array}$ \\
\hline R17 & $\begin{array}{l}\text { Web service } \\
\text { mati secara } \\
\text { tiba-tiba }\end{array}$ & Aplikasi Moodle tidak bisa dibuka \\
\hline $\mathrm{R} 18$ & $\begin{array}{l}\text { Koneksi } \\
\text { jaringan } \\
\text { terputus }\end{array}$ & Kegagalan dalam melakukan akses ke aplikasi Moodle \\
\hline R19 & $\begin{array}{l}\text { Koneksi } \\
\text { jaringan tidak }\end{array}$ & $\begin{array}{l}\text { Kegiatan yang memerlukan akses internet menjadi sangat } \\
\text { lambat }\end{array}$ \\
\hline
\end{tabular}




\begin{tabular}{|c|c|c|}
\hline & stabil & \\
\hline R20 & Sistem crash & $\begin{array}{l}\text { Kerusakan sistem yang menyebabkan aplikasi Moodle tidak } \\
\text { dapat diakses dalam jangka waktu sementara }\end{array}$ \\
\hline $\mathrm{R} 21$ & Gagal update & $\begin{array}{l}\text { Kegagalan dalam melakukan update aplikasi setelah dilakukan } \\
\text { maintenence }\end{array}$ \\
\hline $\mathrm{R} 22$ & Memori penuh & Data tidak bisa tersimpan dalam komputer \\
\hline $\mathrm{R} 23$ & $\begin{array}{l}\text { Kegagalan } \\
\text { software }\end{array}$ & Software tidak bisa berjalan \\
\hline R24 & $\begin{array}{l}\text { Kegagalan } \\
\text { hardware }\end{array}$ & Hardware mengalami kerusakan dan tidak bisa di fungsikan \\
\hline $\mathrm{R} 25$ & Serangan virus & $\begin{array}{l}\text { Komputer terserang virus malware atau sebagainya sehingga } \\
\text { proses bisnis terganggu }\end{array}$ \\
\hline R26 & $\begin{array}{l}\text { Proses } \\
\text { maintenance } \\
\text { tidak terjadwal }\end{array}$ & Menyebabkan sering terjadinya error pada aplikasi Moodle \\
\hline
\end{tabular}

\subsection{Analisis Risiko}

Pada tahap ini dilakukan proses analisis risiko dengan menentukan nilai dari kemungkinan-kemungkinan risiko yang telah diidentifikasi pada tahap sebelumnya. Pada proses ini menggunakan tabel kriteria likelihood yang dibedakan menjadi lima kriteria berdasarkan berapa banyaknya kemungkinan risiko yang terjadi dalam kurun waktu tertentu. Tabel Likelihood dapat dilihat pada Tabel 3.

Tabel 3. Nilai pada Likelihood

\begin{tabular}{|c|c|l|c|}
\hline \multicolumn{2}{|c|}{ Likelihood } & \multicolumn{1}{|c|}{ Deskripsi } & $\begin{array}{c}\text { Frekuensi } \\
\text { Kejadian }\end{array}$ \\
\cline { 1 - 2 } Nilai & Kriteria & & $>2$ tahun \\
\hline 1 & Rare & Risiko tersebut hampir tidak pernah terjadi & $1-2$ tahun \\
\hline 2 & Unlikely & Risiko tersebut jarang terjadi & $7-12$ bulan \\
\hline 3 & Possible & Risiko tersebut kadang terjadi & $4-6$ bulan \\
\hline 4 & Likely & Risiko tersebut sering terjadi & $1-6$ bulan \\
\hline 5 & Certain & Risiko tersebut hampir selalu terjadi & \\
\hline
\end{tabular}

Setelahnya dilakukan tahap penilaian dampak yang terjadi pada objek kasus terhadap kemungkinan risiko yang terjadi. Kriteria penilaian dampak atau impact ini dibedakan berdasarkan seberapa besar dampat yang ditimbulkan untuk mempengaruhi kinerja dari aplikasi Moodle. Nilai dari dampak ini dapat dilihat di tabel impact pada Tabel 4. 
Tabel 4. Nilai Kriteria Impact

\begin{tabular}{|c|l|c|}
\hline \multicolumn{2}{|c|}{ Impact } & \multicolumn{2}{c|}{ Deskripsi } \\
\hline Nilai & Kriteria & \\
\hline 1 & Insignificant & Risiko tidak menganggu aktivitas dan proses bisnis pada instansi \\
\hline 2 & Minor & $\begin{array}{c}\text { Aktivitas pada instansi sedikit terhambat, namun tidak } \\
\text { menganggu aktivitas inti pada instansi }\end{array}$ \\
\hline 3 & Moderate & $\begin{array}{c}\text { Risiko tersebut menganggu jalannya proses bisnis pada instansi, } \\
\text { sehingga sebagian jalannya aktivitas terhambat }\end{array}$ \\
\hline 4 & Major & $\begin{array}{c}\text { Risiko tersebut menghambat hampir seluruh jalannya proses } \\
\text { bisnis pada instansi }\end{array}$ \\
\hline 5 & Catastrophic & $\begin{array}{c}\text { Risiko mengganggu jalannya proses bisnis yang ada secara } \\
\text { menyeluruh dan menghentikan aktivitas instansi secara total }\end{array}$ \\
\hline
\end{tabular}

Setelah mendapatkan kriteria kemungkinan (Likelihood) di tabel 3, dan kriteria dampak (Impact) di tabel 4. Berikutnya memberikan penilaian pada setiap kemungkinan risiko berdasarkan tabel 3 dan 4.

Tabel 5. Penilaian Likelihood dan Impact

\begin{tabular}{|l|l|c|c|}
\hline Id & Kemungkinan Risiko & Likelihood & Impact \\
\hline R01 & Banjir & $\mathbf{1}$ & $\mathbf{3}$ \\
\hline R02 & Gempa Bumi & $\mathbf{2}$ & $\mathbf{4}$ \\
\hline R03 & Petir & $\mathbf{1}$ & $\mathbf{3}$ \\
\hline R04 & Kebakaran & $\mathbf{3}$ & $\mathbf{3}$ \\
\hline R05 & Listrik Padam & $\mathbf{4}$ & $\mathbf{3}$ \\
\hline R06 & Human Error & $\mathbf{2}$ & $\mathbf{2}$ \\
\hline \multirow{2}{*}{ R07 } & Data dan Informasi diakses oleh pihak yang tidak & & \\
& berwenang & $\mathbf{2}$ & $\mathbf{2}$ \\
\hline R08 & Penyalahgunaan hak akses & $\mathbf{1}$ & $\mathbf{3}$ \\
\hline R09 & Vandalisme & $\mathbf{1}$ & $\mathbf{3}$ \\
\hline R10 & Cybercrime & $\mathbf{4}$ & $\mathbf{4}$ \\
\hline R11 & Server down & $\mathbf{1}$ & $\mathbf{2}$ \\
\hline R12 & Backup Failure & $\mathbf{3}$ & $\mathbf{1}$ \\
\hline R13 & Overheat & $\mathbf{1}$ & $\mathbf{4}$ \\
\hline R14 & Data corrupt & $\mathbf{3}$ & $\mathbf{1}$ \\
\hline R15 & Overcapacity & $\mathbf{4}$ & $\mathbf{4}$ \\
\hline R16 & Overload & $\mathbf{4}$ & $\mathbf{4}$ \\
\hline R17 & Web service mati secara tiba-tiba & $\mathbf{3}$ & $\mathbf{3}$ \\
\hline R18 & Koneksi jaringan terputus & $\mathbf{4}$ & $\mathbf{3}$ \\
\hline R19 & Koneksi jaringan tidak stabil & $\mathbf{3}$ & $\mathbf{4}$ \\
\hline R20 & Sistem crash & $\mathbf{1}$ & $\mathbf{2}$ \\
\hline R21 & Gagal update & $\mathbf{3}$ & $\mathbf{3}$ \\
\hline R22 & Memori penuh & $\mathbf{2}$ & $\mathbf{3}$ \\
\hline R23 & Kegagalan software & $\mathbf{3}$ \\
\hline R24 & Kegagalan hardware & $\mathbf{2}$ \\
\hline R25 & Serangan virus & & \\
\hline R26 & Proses maintenance tidak terjadwal & $\mathbf{3}$ \\
\hline
\end{tabular}


Dari tabel 5 diatas, ditemukan nilai-nilai likelihood dan impact dari kemungkinan risiko yang ada pada tabel Likelihood dan Impact. Kemudian setelah ditemukan nilai dari Likelihood dan Impact, masuk pada tahap evaluasi risiko.

\subsection{Evaluasi Risiko}

Tahapan terakhir yaitu evaluasi risiko, dilakukan proses evaluasi dari kemungkinan kemungkinan risiko yang terdapat pada analisis tahapan sebelumnya. Hasil analisis tersebut dimasukkan pada matrix evaluasi risiko, matrix evaluasi tersebut dikategorikan menjadi 3 level risiko yaitu : Low, Medium, dan High. Selanjutnya memasukkan setiap ID kemungkinan risiko kedalam matrix evaluasi risiko sesuai dengan kriteria Likelihood dan kriteria Impact.

Tabel 6. Matrix Evaluasi Risiko Berdasarkan Likelihood dan Impact

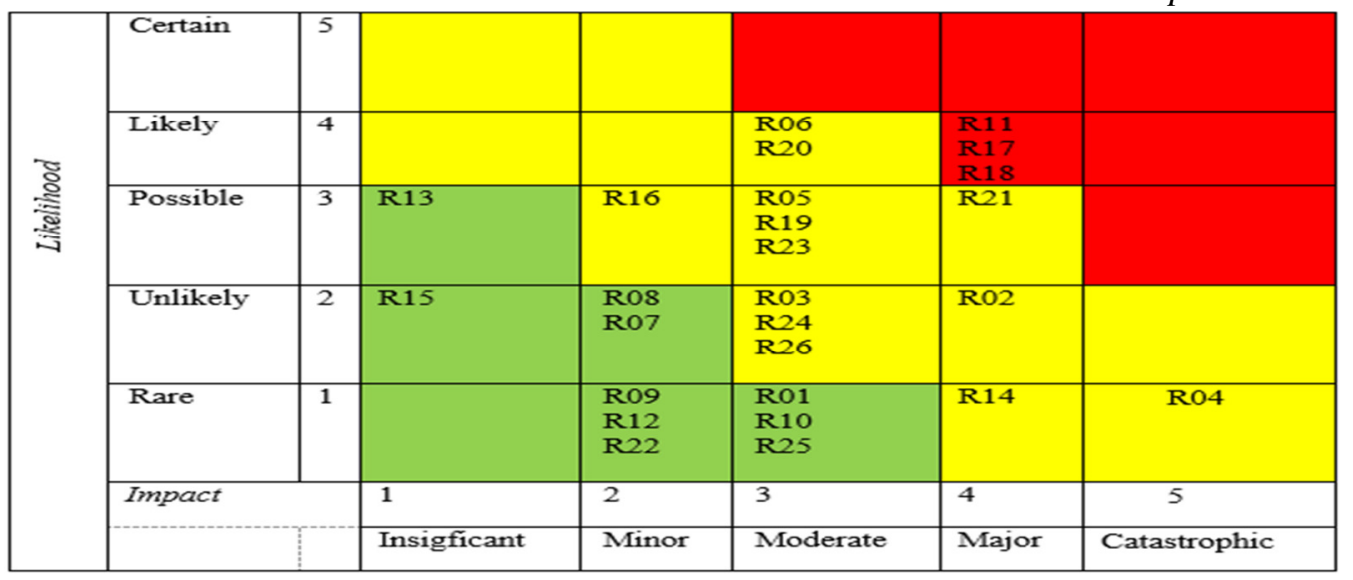

Dari hasil Likelihood dan Impact terdapat 26 kemungkinan risiko yang dapat dikategorikan dengan rasio yang sesuai seperti pada tabel 6 .

Setelah memasukan kemungkinan risiko ke dalam matrix evaluasi berdasarkan Likelihood dan Impact, berikutnya akan di dikelompokkan sesuai dengan tingkatan 26 kemungkinan risiko tersebut kedalam tingkatan level high, medium dan low.

Tabel 7. Pengelompokkan Risiko Berdasarkan Tingkatan

\begin{tabular}{|l|l|l|l|l|}
\hline Id & Kemungkinan Risiko & Likelihood & Impact & Risk Level \\
\hline R11 & Server down & $\mathbf{4}$ & $\mathbf{4}$ & High \\
\hline R17 & Web service mati secara tiba-tiba & $\mathbf{4}$ & $\mathbf{4}$ & High \\
\hline R18 & Koneksi jaringan terputus & $\mathbf{4}$ & $\mathbf{4}$ & High \\
\hline R21 & Gagal update & $\mathbf{3}$ & $\mathbf{4}$ & Medium \\
\hline R06 & Human Error & $\mathbf{4}$ & $\mathbf{3}$ & Medium \\
\hline R20 & Sistem crash & $\mathbf{4}$ & $\mathbf{3}$ & Medium \\
\hline R05 & Listrik Padam & $\mathbf{3}$ & $\mathbf{3}$ & Medium \\
\hline R19 & Koneksi jaringan tidak stabil & $\mathbf{3}$ & $\mathbf{3}$ & Medium \\
\hline R23 & Kegagalan software & $\mathbf{3}$ & $\mathbf{3}$ & Medium \\
\hline R02 & Gempa Bumi & $\mathbf{2}$ & $\mathbf{4}$ & Medium \\
\hline R16 & Overload & $\mathbf{3}$ & $\mathbf{2}$ & Medium \\
\hline R03 & Petir & $\mathbf{2}$ & $\mathbf{3}$ & Medium \\
\hline R24 & Kegagalan hardware & $\mathbf{2}$ & $\mathbf{3}$ & Medium \\
\hline R26 & Proses maintenance tidak terjadwal & $\mathbf{2}$ & $\mathbf{3}$ & Medium \\
\hline
\end{tabular}

Kanantyo, et., al [Analisis Risiko Teknologi Informasi Menggunakan ISO 31000 (Learning Management System SMPN 6 Salatiga)] 


\begin{tabular}{|l|l|l|l|l|}
\hline R04 & Kebakaran & $\mathbf{1}$ & $\mathbf{5}$ & Medium \\
\hline R14 & Data corrupt & $\mathbf{1}$ & $\mathbf{4}$ & Medium \\
\hline R08 & Penyalahgunaan hak akses & $\mathbf{2}$ & $\mathbf{2}$ & Low \\
\hline R07 & Data dan Informasi tidak sesuai & $\mathbf{4}$ & $\mathbf{4}$ & Low \\
\hline R13 & Overheat & $\mathbf{3}$ & $\mathbf{1}$ & Low \\
\hline R15 & Overcapacity & $\mathbf{2}$ & $\mathbf{1}$ & Low \\
\hline R01 & Banjir & $\mathbf{1}$ & $\mathbf{3}$ & Low \\
\hline R10 & Cybercrime & $\mathbf{1}$ & $\mathbf{3}$ & Low \\
\hline R25 & Serangan virus & $\mathbf{1}$ & $\mathbf{3}$ & Low \\
\hline R09 & Vandalisme & $\mathbf{1}$ & $\mathbf{2}$ & Low \\
\hline R12 & Backup Failure & $\mathbf{1}$ & $\mathbf{3}$ & Low \\
\hline R22 & Memori penuh & $\mathbf{1}$ & $\mathbf{2}$ & Low \\
\hline
\end{tabular}

Pada tabel 7 datas, tahapan proses evaluasi risiko, terdapat 26 kemungkinan risiko yang sudah dianalisis dan dikategorikan sesuai dengan level risikonya. Terdapat 3 risiko dengan tingkatan high yaitu: R11, R17 dan R18. Lalu 13 risiko dengan tingkatan medium yaitu: R21, R06, R20, R05, R19, R23, R02, R16, R03, R24, R26, R04, R14. Dan terakhir 10 risiko dengan tingkatan low yaitu: R07, R08, R13, R15, R01, R10, R25, R09, R12, R22.

\subsection{Perlakuan Risiko}

Setelah analisis risiko diatas, maka selanjutnya akan masuk pada tahap Risk Treatment atau perlakuan risiko. Pada tahap ini dilakukan pemberian usulan tindakan risiko terhadap kemungkinan risiko yang sudah di kelompokkan berdasarkan risk level pada tabel 8.

Tabel 8. Usulan Perlakuan Risiko

\begin{tabular}{|l|l|l|l|}
\hline Id & \multicolumn{1}{|c|}{$\begin{array}{c}\text { Kemungkinan } \\
\text { Risiko }\end{array}$} & $\begin{array}{c}\text { Risk } \\
\text { Level }\end{array}$ & \multicolumn{1}{c|}{ Tindakan Risiko } \\
\hline R11 & Server down & High & Melakukan pengecekan berskala pada database \\
\hline R17 & $\begin{array}{l}\text { Web service mati } \\
\text { secara tiba-tiba }\end{array}$ & High & $\begin{array}{l}\text { Memberikan pemberitahuan kepada user saat web } \\
\text { service mati. Melakukan troubleshooting saat web } \\
\text { service mati. }\end{array}$ \\
\hline R18 & $\begin{array}{l}\text { Koneksi jaringan } \\
\text { terputus }\end{array}$ & High & $\begin{array}{l}\text { Mengganti ISP (Internet Service Proider) dengan } \\
\text { yang baru }\end{array}$ \\
\hline R21 & Gagal update & Medium & $\begin{array}{l}\text { Setelah ditemukan beberapa kesalahan sistem } \\
\text { segera melakukan perbaikan sistem. }\end{array}$ \\
\hline R20 & Human Error & Medium & Melakukan training pada setiap SDM \\
\hline Sistem crash & Medium & $\begin{array}{l}\text { Melakukan perbaikan jika ditemukan kesalahan } \\
\text { sistem pada saat melakukan maintenence }\end{array}$ \\
\hline R19 & $\begin{array}{l}\text { Koneksi jaringan } \\
\text { tidak stabil }\end{array}$ & Medium & $\begin{array}{l}\text { Menyediakan generator set listrik dengan daya } \\
\text { yang sesuai dengan kebutuhan. Kemudian } \\
\text { menyiapkan Uninterruptible Power Supply (UPS) }\end{array}$ \\
\hline R23 & $\begin{array}{l}\text { Kegagalan } \\
\text { software }\end{array}$ & Medium & $\begin{array}{l}\text { Melakukanti ISP (Internet Service Proider) dengan } \\
\text { resource lainya pada PC, jika diperlukan melakukan } \\
\text { install ulang pada OS }\end{array}$ \\
\hline R02 & Gempa Bumi & Medium & $\begin{array}{l}\text { Menyediakan tempat yang aman untuk perangkat- } \\
\text { perangkat yang ada }\end{array}$ \\
\hline Overload & Medium & $\begin{array}{l}\text { Melakukan refresh penggunaan db log, temp, dan } \\
\text { RAM. Serta melakukan pengecekan terhadap } \\
\text { database perusahaan }\end{array}$ \\
\hline
\end{tabular}




\begin{tabular}{|c|c|c|c|}
\hline R03 & Petir & Medium & Memasang alat penangkal petir \\
\hline $\mathrm{R} 24$ & $\begin{array}{l}\text { Kegagalan } \\
\text { hardware }\end{array}$ & Medium & $\begin{array}{l}\text { Memberikan asuransi terhadap aset hardware yang } \\
\text { ada }\end{array}$ \\
\hline $\mathrm{R} 26$ & $\begin{array}{l}\text { Proses } \\
\text { maintenance tidak } \\
\text { terjadwal }\end{array}$ & Medium & $\begin{array}{l}\text { Melakukan penjadwalan maintenance rutin setiap } \\
\text { minggu }\end{array}$ \\
\hline R04 & Kebakaran & Medium & Menyiapkan alat pemadam kebakaran \\
\hline R14 & Data corrupt & Medium & Melakukan backup data secara berskala \\
\hline R08 & $\begin{array}{l}\text { Penyalahgunaan } \\
\text { hak akses }\end{array}$ & Low & Memberikan batasan akses pada setiap user \\
\hline R07 & $\begin{array}{l}\text { Data dan } \\
\text { Informasi diakses } \\
\text { oleh pihak yang } \\
\text { tidak berwenang }\end{array}$ & Low & Memberikan batasan akses pada setiap user \\
\hline R13 & Overheat & Low & $\begin{array}{l}\text { Menyediakan ruang yang memiliki AC (Air } \\
\text { Conditioner) dan menambah fan pada semua } \\
\text { hardware }\end{array}$ \\
\hline $\mathrm{R} 15$ & Overcapacity & Low & $\begin{array}{l}\text { Menambah kapasitas memori yang lebih besar agar } \\
\text { daya tampungnya lebih optimal. Melakukan cek } \\
\text { memori secara berkala. }\end{array}$ \\
\hline R01 & Banjir & Low & $\begin{array}{l}\text { Meletakkan alat alat infrastruktur di tempat yang } \\
\text { aman dari banjir }\end{array}$ \\
\hline R10 & Cybercrime & Low & Mengganti password server secara berkala. \\
\hline $\mathrm{R} 25$ & Serangan virus & Low & $\begin{array}{l}\text { Melakukan scanning antivirus terhadap portable } \\
\text { device, dan selalu mengaktifkan firewall dan } \\
\text { internet security }\end{array}$ \\
\hline R09 & Vandalisme & Low & $\begin{array}{l}\text { Memasang dan memantau CCTV di gedung } \\
\text { perusahaan. }\end{array}$ \\
\hline $\mathrm{R} 12$ & Backup Failure & Low & $\begin{array}{l}\text { Memperhatikan penggunaan memori yang } \\
\text { digunakan database agar jangan sampai penuh. } \\
\text { Membuat maintenance plan yang tepat. Serta } \\
\text { membuat SOP dan melakukan backup data secara } \\
\text { berkala. }\end{array}$ \\
\hline R22 & Memori penuh & Low & $\begin{array}{l}\text { Menambah kapasitas memori yang lebih besar agar } \\
\text { daya tampungnya lebih optimal. Melakukan cek } \\
\text { memori secara berkala. }\end{array}$ \\
\hline
\end{tabular}

Dalam tabel 8 diatas ini diharapkan dapat meminimalisir kemungkinan risiko yang dapat terjadi pada aplikasi Moodle.

\section{KESIMPULAN}

Berdasarakan penelitian Manajemen Risiko menggunakan ISO 31000 yang dilakukan di SMP N 6 Salatiga pada kasus Learning Management System yang menerapkan e-Learning menggunakan aplikasi Moodle terdapat beberapa tahapan mulai dari penilaian risiko, identifikasi risiko, analisis risiko, evaluasi risiko, hingga pada tahap perlakuan risiko. Dapat ditemukan 26 risiko yang menyebabkan aplikasi proses bisnis di SMP N 6 Salatiga menjadi terganggu.

Dalam penelitian ditemukan 3 kemungkinan risiko dengan tingkatan High seperti Server Down, Web service yang sering mati, serta koneksi jaringan yang sering terputus. 
Kemudian terdapat 13 risiko dengan tingkatan medium, meliputi Kegagalan software, sistem crash, human error, koneksi jaringan tidak stabil, gempa bumi, petir, kerusakan hardware, proses maintenence tidak terjadwal, overload, serta data corrupt. Selain itu juga terdapat 10 risiko dengan tingkatan low, seperti penyalahgunaan hak akses, overheat, overcapacity, banjir, cybercrime, serangan virus, vandalisme, kegagalan backup, serta memori penuh.

Setelah dilakukan penelitian ini diharapkan penelitian ini dapat digunakan sebagai pedoman bagi SMP N 6 Salatiga untuk mengurangi atau meminimalisit kemungkinan risiko yang dapat disebabkan oleh berbagai macam hal seperti yang sudah disebutkan diatas dengan menerapkan perlakuan risiko dari tabel 10 seperti mengganti ISP terbaru, melakukan troubleshooting ketika web service mati, serta melakukan pengecekan berskala pada database, sehingga proses bisnis dalam SMP N 6 Salatiga dapat berjalan dengan baik.

\section{SARAN}

Untuk penelitain kedepannya diharapkan penulis dapat mengembangkan lagi penelitian ini dengan metode yang lebih relefan kedepannya, karena kemungkianan aplikasi yang diterapkan akan terus berkembang.

\section{UCAPAN TERIMAKASIH}

Penulis mengucapkan terimakasih kepada kedua orangtua yang telah memberikan dukungan finansial dan moral, tak lupa juga kepada pembimbing yang telah memberkan arahan dan masukan sehingga jurnal ini dapat tersusun dengan baik, serta kepada pihak SMP N 6 Salatiga yang telah berkenan untuk memberikan data serta informasi yang digunakan untuk penelitian ini, dan juga teman-teman yang selalu memberi dukungan moral.

\section{DAFTAR PUSTAKA}

[1] N. Arnesti and A. Hamid, 2015, "Penggunaan Media Pembelajaran Online - Offline dan Komunikasi Interpersonal Terhadap Hasil Belajar Bahasa Inggris," J. Teknol. Inf. Komun. Dalam Pendidik., Vol. 2, No. 1, doi: 10.24114/jtikp.v2i1.3284.

[2] S. Rizal and B. Walidain, 2019, "Pembuatan Media Pembelajaran E-Learning Berbasis Moodle pada Matakuliah Pengantar Aplikasi Komputer Universitas Serambi Mekkah," J. Ilm. Didakt. Media Ilm. Pendidik. dan Pengajaran, Vol. 19, No. 2, p. 178, doi: 10.22373/jid.v19i2.5032.

[3] U. Nugraha and R. Istambul, 2019 "Implementation of ISO 31000 for Information Technology Risk Management In The Government Environment,” Int. J. Innov. Creat. Chang., Vol. 6, No. 5, pp. 219-231,.

[4] H. T. I. Driantami, Suprapto, and A. R. Perdanakusuma, 2018 "Analisis Risiko Teknologi Informasi Menggunakan ISO 31000 (Studi Kasus: Sistem Penjualan PT Matahari Department Store Cabang Malang Town Square)," J. Pengemb. Teknol. Inf. dan Ilmu Komput., Vol. 2, No. 11, pp. 4991-4998,. 
[5] A. Novia Rilyani, Y. A. Firdaus W ST, and D. S. Dwi Jatmiko, 2015. "Analisis Risiko Teknologi Informasi Berbasis Risk Management Menggunakan ISO 31000 (Studi Kasus : i-Gracias Telkom University) Information Technology Risk Analysis Based On Risk Management Using Iso 31000 (Case Study: i-Gracias Telkom University)," eProceeding Eng., Vol. 2, No. 2, pp. 6201-6208,

[6] G. W. Lantang, A. D. Cahyono, and N. Ngalumsine, 2019, "Analisis Risiko Teknologi Informasi pada Aplikasi SAP di PT Serasi Autoraya Menggunakan Iso 31000,” Sebatik 2621-069X, Vol. 23 No. 1, pp. 36-43, doi: 1410-3737.

[7] F. L. Nice and R. V. Imbar, 2017 “Analisis Risiko Teknologi Informasi pada Lembaga Penerbangan dan Antariksa Nasional (LAPAN) pada Website SWIFTS Menggunakan ISO 31000," J. Inform. dan Sist. Inf., Vol. 2, No. 2, pp. 1-11,.

[8] M. Monica, didik Kurniawan, and R. Prabowo, 2020, "Analisis Manajemen Risiko Sistem Informasi Pengelolaaan Data English Proficiency Test (EPT) dan Portal Informasi di UPT Bahasa Universitas Lampung Menggunakan Metode ISO 31000,” J. Komputasi, Vol. 8, No. 1, pp. 83-90, doi: 10.23960/komputasi.v8i1.2351.

[9] D. L. Ramadhan, R. Febriansyah, and R. S. Dewi, 2020, "Analisis Manajemen Risiko Menggunakan ISO 31000 pada Smart Canteen SMA XYZ," JURIKOM (Jurnal Ris. Komputer), Vol. 7, No. 1, p. 91, doi: 10.30865/jurikom.v7i1.1791.

[10] F. M. Hutabarat and A. D. Manuputty, 2020, "Analisis Resiko Teknologi Informasi Aplikasi VCare PT Visionet Data Internasional Menggunakan ISO 31000,” J. Bina Komput., Vol. 2, No. 1, pp. 52-65, doi: 10.33557/binakomputer.v2i1.792. 